\title{
Research Self-Efficacy, Interest in Research and Research Knowledge of Graduate Students
}

\author{
Jovelyn G Delosa, Charity Rose A Pagara, Edralin C. Manla \\ School of Education, Xavier University, Philippines
}

\begin{abstract}
One of the goals of graduate education is to produce graduates equipped with excellent research skills. With the challenges on the quality education and demands on excellence, the current priority of the Commission of Higher Education is on research. Graduate schools offering graduate programs are mandated to guide students develop the research skills expected of them. The purpose of this study is to determine how specific factors such as research efficacy and research interest contributed to research knowledge of the students. The participants of the study are the Master's and Doctoral student enrolled in the school. The study utilized descriptive research design. The results showed that the Graduate students have good research interest and good level of self-efficacy, but poor research knowledge. Moreover, there is a significant contribution of interest in research to research knowledge, but a negative contribution of research self-efficacy to students' research knowledge. These findings imply that the development of the graduate students' research interest should be prioritized by the School of Education. These also denotes that there could be other factors to be looked into that may have contribution to students' research knowledge, not only efficacy and interest.
\end{abstract}

Keywords - research self-efficacy, interest in research, research knowledge, graduate research, graduate programs

\section{INTRODUCTION}

$\mathrm{R}$ esearch plays a major role in the graduate school curriculum. Research preparation is vital in the education profession. Graduate students are expected to be better research writers with advanced writing abilities to cope with the demands of their academic requirements. The creation of Higher Education Act of 1994, RA No. 7722, monitors the level or degree of standards in the tertiary and graduate education in the areas of institution, research and extension. With the challenges on the quality education and demands on excellence, the current priority of the Commission of Higher Education is on research. However, graduate students are experiencing research difficulties (Rogers, 2010) in constructing scholarly work, doing statistics and writing professional literature. In addition, students often hold negative attitude towards research courses (Boswell, 2013) thus the attitude towards research is of importance in their research related-tasks. Moreover, some graduate students were observed to delay the making of their required research proposal. Literature has reported that graduate students are experiencing research difficulties and there are non-cognitive factors which contributed to the acquisition of research knowledge.

This study is anchored on Albert Bandura's (1994), self-efficacy theory. It is defined as ones' beliefs on their capability to do a particular task. People with high regard of their capability looked at difficult tasks as challenges and can sustain their efforts over difficult tasks. Bandura explained as shown in the figure below that there are three determinants which interplay with each other resulting to a particular human functioning.

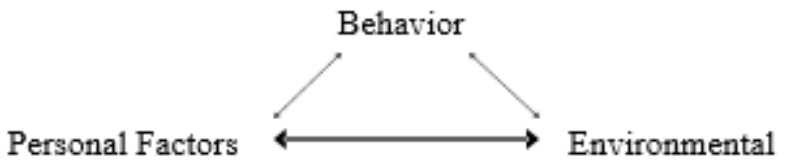

Figure 1. The interplay of the determinants

Self-efficacy beliefs can influence human functioning and how a person can exert his efforts on a difficult task and how he perseveres to achieve his goals.

The Graduate Studies of the School of Education plays a crucial role in guiding graduate students to pursue quality research (CMO no. 53, s. 2007). The University President supported the attainment of this goal through restructuring the organization in such a way that research of faculty and students be given priority. It is timely to determine how SOE's Master and PhD students are faring in their research activities which are taken during a Research class or research tasks integrated in their courses.

Research difficulties include non-cognitive factors such as fear, time and stress management (Bocar, 2014) and lack of motivation and confidence in the conduct of research. In the study of Tiyuri, Saberi, Miri, Shahrestanaki, Bayat and Salehiniya (2018), research self-efficacy is one of the main factors influencing the successful conduction of research and following it in students. As a direct and significant relationship existed between research self-efficacy score and student's academic performance, improving the research self-efficacy will also increase students' academic performance. Hence, research difficulties can be attributed primarily to the students' self-efficacy in dealing with research. According to Bandura (1994), people who doubt their capabilities shy away from difficult tasks which they view as personal threats. They have low 
aspirations and weak commitment to the goals they choose to pursue. The researchers are interested to explore students' areas of strength and areas which need to be developed in terms of doing research. According to Potvin and Hasni (2014), Interest is seen as something that drives positive action toward the object of interest; an intrinsic reason or motivation, and also sometimes seen as the key factor in making decisions.

The purpose of this study is to determine how specific factors, such as research self- efficacy and research interest, contributed to how much research knowledge the students can achieve. Specifically, the study aims to determine the respondents' level of research selfefficacy, research interest and knowledge in research highlighting the different indicators under each variable.

\section{METHODOLOGY}

In this study the descriptive method of research was used. The respondents of this study are the Graduate Students who are currently enrolled in the Masters and Doctoral Programs in the School of Education, of a private university, for the school year 2016-2017. The statistics used were descriptive statistics (mean and standard deviation) for the distribution of the results of selfefficacy, research knowledge and interest in research, and inferential statistics, specifically multiple linear regression to test the effect of self-efficacy and interest in research towards research knowledge.

There are three- questionnaires used in this study. These are Research Knowledge Assessment (RKA), with permission from the author, a researcher-made Research Self- Efficacy Tool (RSET) and a researchermade questionnaire on Interest in Research.

The Self-Efficacy Scale is a 30-item questionnaire which was used to measure the perceived ability to perform research tasks and activities. These research tasks and activities would include from the start of thinking on what idea or topic for a research and crafting research questions, until the presentation of the final research output to a group. The Interest on Research Questionnaire is a 15-item instrument which measured the respondents' interest to do research activities through a research team or individually. The Research Knowledge Assessment measures the students' understanding of research concepts and is a multiple choice 50-item assessment, designed to measure graduate education students' knowledge of research methodology. A permission was granted to use this tool from Dr Glen Lambie, PhD from the University of Central Florida (RKA@; Lambie, Hayes, Griffith, Limberg, \& Mullen, 2014) It consists of eight subscales: (a) literature reviews, (b) ethics in educational research, (c) research designs, (d) sampling, (e) data collection methodologies, (f) data analysis procedures, (g) data reporting, and (h) scholarly writing practices. The tools were piloted and produce the reliability indices of $0.76,0.80$ and 0.79 respectively. A reliability test was also conducted using Rasch analysis of the three tools. The research knowledge has a person reliability of 0.70 and an item reliability of 0.85 . The research interest questionnaire obtained a person reliability of .91 and an item reliability of .72 . The Research self-efficacy instrument has a person reliability of .93. Permissions were requested from the respondents through an informed consent and from the Office of the School of Education (see appendix A-C). In this study, the following terms are operationally defined for clarity and better understanding.

\section{RESULTS}

Table 1 shows the students' level of selfefficacy in doing research. The results reported a mean of 2.90 which is described as Good. The rating of Fair got nearly half of the percentage of the respondents.

The result implies that the respondents' perceived ability in conducting research is only "good" and thus still needs to be improved.

Table 1: Level of Research Self-Efficacy of the Graduate Students $[\mathrm{n}=53]$

\begin{tabular}{|c|c|c|}
\hline Level of Research Self-Efficacy & Mean & Desc \\
\hline Over-all Research Self-Efficacy & 2.90 & Good \\
\hline \multicolumn{3}{|l|}{ Indicators } \\
\hline 1. Completing a research project & 2.89 & Good \\
\hline 2. Following ethical principles of research & 3.09 & Good \\
\hline 3. Conducting a computer search of the & 2.92 & Good \\
\hline literature to be used in the area of research & & \\
\hline 4. Locating references by manual search & 2.63 & Fair \\
\hline $\begin{array}{l}\text { 5. Searching needed articles in the library and } \\
\text { database }\end{array}$ & 2.75 & Fair \\
\hline $\begin{array}{l}\text { 6. Evaluating journal articles in terms of } \\
\text { t he theoretical frameworks, designs, and } \\
\text { data analysis techniques used }\end{array}$ & 2.62 & Fair \\
\hline $\begin{array}{l}\text { 7. Participating in generating collaborative } \\
\text { research ideas }\end{array}$ & 2.66 & Fair \\
\hline 8. Working independently in a research group & 2.74 & Fair \\
\hline 9. Discussing research with peers & 3.13 & Good \\
\hline $\begin{array}{l}\text { 10. Consulting senior researchers for research } \\
\text { ideas }\end{array}$ & 3.04 & Good \\
\hline 11. Identifying research gaps & 2.70 & Fair \\
\hline 12. Crafting researchable questions & 2.70 & Fair \\
\hline $\begin{array}{l}\text { 13. Organizing your proposed research ideas } \\
\text { in writing }\end{array}$ & 2.91 & Good \\
\hline $\begin{array}{l}\text { 14. Editing your writing to make it logical and } \\
\text { organized }\end{array}$ & 2.83 & Good \\
\hline $\begin{array}{l}\text { 15. Presenting your research ideas orally or in } \\
\text { written form to an advisor or group }\end{array}$ & 3.02 & Good \\
\hline 16. Choosing an appropriate research design & 3.02 & Good \\
\hline $\begin{array}{l}\text { 17. Choosing correct methods of data } \\
\text { collection }\end{array}$ & 2.81 & Good \\
\hline $\begin{array}{l}\text { Choosing measures of dependent and independent } \\
\text { variables }\end{array}$ & 2.89 & Good \\
\hline $\begin{array}{l}\text { 19. Choosing appropriate data analysis } \\
\text { techniques }\end{array}$ & 2.70 & Fair \\
\hline 20. Obtain approval to pursue research & 2.85 & Good \\
\hline $\begin{array}{l}\text { Working on the statistical analyses of the research } \\
\text { paper }\end{array}$ & 2.89 & Good \\
\hline 22. Develop Research instruments & 2.79 & Fair \\
\hline
\end{tabular}




\begin{tabular}{l|l|l|}
\hline 23. Writing critical literature reviews & 3.04 & Good \\
24. Ensure data collection is reliable & 2.89 & Good \\
25. Identifying the appropriate theory for the study & 3.25 & Good \\
26. Organizing collected data for analysis & & \\
27. Identifying the variables/ constructs in the & 3.11 & Good \\
study & 3.19 & Good \\
28. Validating research instruments & & \\
29. Using a computer for data analysis & 2.98 & Good \\
30. Using statistical soft wares to analyze data & 3.15 & Good \\
& 2.92 & Good \\
\hline
\end{tabular}

As presented in Table 1, most of the indicators are rated as "good" while there are few indicators which are rated as "fair". These indicators are: a) Locating references by manual search, b) Searching needed articles in the library and database, c.) Evaluating journal articles in terms of the theoretical frameworks, designs, and data analysis techniques used, d)Participating in generating collaborative research ideas, e)Working independently in a research group, f) Identifying research gaps, g). Crafting researchable questions, h.) Choosing appropriate data analysis techniques and i) developing research instruments.

These indicators are the abilities in conducting research which the respondents perceived themselves as having only a "fair" capability.

Table 2 reveals that the students' interest in research is rated as Good with a mean of 2.87. Most of the students are in the 'Good 'and 'Fair' ratings.

Table 2: Graduate Students' Interest In Research

$[\mathrm{N}=53]$

\begin{tabular}{|l|c|c|}
\hline Interest in Research & Mean & Desc \\
\hline \multicolumn{1}{|c|}{ Over-all Interest in Research } & 2.87 & Good \\
\hline & & \\
Indicators & 3.09 & Good \\
Reading a research article & 2.92 & Good \\
Being a member of a research team & 2.43 & Fair \\
Leading a research team & 2.70 & Fair \\
Conceptualize a research study & 2.57 & Fair \\
Conducting a literature review & 2.94 & Good \\
Collecting data & 2.81 & Good \\
Analyzing data & 3.17 & Good \\
Discussing research findings with colleagues & & \\
Writing for publication & 2.89 & Good \\
Presenting a paper & 3.04 & Good \\
Discussing appropriate research methodology & 2.75 & Fair \\
with colleagues & & \\
Participating in a research forum & 3.15 & Good \\
Seeking funds for research projects & 2.87 & Good \\
Developing research instruments & 2.74 & Fair \\
Validating research instruments & 2.92 & Good \\
& & \\
\hline
\end{tabular}

Based from the results, there are five indicators which were rated as "fair". The respondents have "fair" interest in research specifically in the indicators 3-5, which refers to leading a research team, conceptualizing a research study and conducting a literature review. Indicators 11 and 14 were also rated as "fair", which refers to discussing appropriate research methodology with colleagues and developing research instruments. These results imply that the respondents clearly have less interest in research especially in the indicators mentioned above, which are all very important in the making of research. Other indicators were rated as "good", which still needs an improvement, since interest is very important for one's motivation to conduct research.

In the study of Congdon (2011), the primary emphasis was to engage students in a democratic collaborative learning process in order to develop skills and students and co-researchers as a means to facilitate the research learning process. The findings revealed that the relinquishment of power to student was pivotal to the success of the participatory approach to learning.

Figure 1 reports an over-all mean of 25.55 which is described as 'Poor'. It can be observed from the indicators that the components of research include both concepts in quantitative and qualitative research.

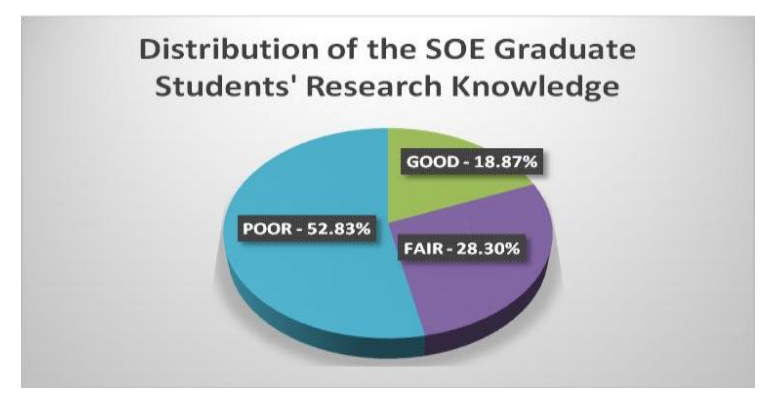

Over-all Mean $=25.55 \quad$ Poor sd $=6.08$

Figure 1. Distribution Of The School Of Education (Soe) Graduate Students' Research Knowledge

Most of the indicators with small percentage of correct response are more on concepts of qualitative researches. However, it can be gleaned from the indicators that there are also basic concepts of research which are more on quantitative design, that resulted to small percentages and these indicators are very helpful in improving research skills. In general, all indicators have percentages below $50 \%$ which is quite alarming, and therefore implies that the general knowledge of the respondents is very poor. This can be attributed to one factor wherein the exposure of the graduate students, is more on the quantitative research design. In addition, there might be a lacking of provision in research experiences. According to Jang and Shin (2011), an early provision of experience and formation of interest in research are more important than the provision of research support program and activities, with the exception of research education.

Table 3 displays the summary of the multiple linear regression analysis between the students' self-efficacy, research interest and research knowledge. As shown in the table, the regression model is significant $(\mathrm{F}=$ $3.29, \mathrm{P}=0.04)$. There is a positive contribution of interest in research to research knowledge (coefficient $=4.60$ ). 
However, there is a negative contribution of selfefficacy (coefficient=-3.23) to research knowledge. This negative contribution implies an inverse relationship between respondents' self-efficacy and research knowledge. Only $8 \%$ of the variation of the data in the research knowledge is explained by research self-efficacy and interest in research. This means that the other $92 \%$ of the variation of the data is explained by other factors such as training and exposure.

Table 3. Extent Of Contribution Of Students' Research Self-Efficacy And Interest In Research To Their Research Knowledge

\begin{tabular}{|l|c|c|c|}
\hline \multicolumn{5}{|c|}{ Dependent Variable: Research Knowledge } \\
\hline \multicolumn{1}{|c|}{ Independent Variable } & Coefficient & $\mathrm{T}$ & Probability \\
\hline Level of Self-Efficacy & -3.23 & -1.68 & 0.0499 \\
Interest in Research & 4.60 & 2.56 & 0.014 \\
\hline \multicolumn{4}{|c|}{ Regression Model: $\hat{\mathrm{y}}=19.45-3.23 \mathrm{x}_{1}+4.60 \mathrm{x}_{2}$} \\
\hline \multicolumn{4}{|c|}{ Intercept $=19.45$} \\
$\mathrm{R}=0.34$ \\
Adjusted $\mathrm{R}^{2}=0.0811$ \\
$\mathrm{~F}=3.29$ \\
Significance $\mathrm{F}=0.045$ (Significant at 0.05 level) \\
\hline
\end{tabular}

Note: The variables passed the test of multicollinearity $(\mathrm{r}=0.58,-0.03,0.26)$

\section{DISCUSSION}

The self-efficacy and of the students are both rated as Good however the results of the means fall between scales of Good and Fair. Research knowledge of the students is rated as Very Poor. The lowest responses are from items about establishing ethical frameworks with a very low percentage of correct response (5\%); identifying differences between research designs $(6 \%$ correct response); determining the characteristics of a quasiexperimental research design $(8 \%$ correct response); identifying types of validity $(6 \%$ correct response); and determining appropriate sampling procedures $(8 \%$ correct response). There were also high rates of responses on items about outlining the purposes of research (485 correct response); differentiating primary from secondary sources (40\% correct response); identifying measures of variability (41\% correct response); using APA guidelines (46\% correct response).

In this study, the multiple linear regression can be used because there is no multicollinearity among the variables when taken as a whole, however caution must be observed because a closer examination of some individual items in self- efficacy produce similar characteristics with related items in the research interest instrument. The results of the multiple linear regression show that research interest positively predicts students' research knowledge. Studies showed that many factors have been investigated to identify what affects research knowledge of graduate students. It is not so much on self-efficacy but on the research experiences provided to the students (Chesnut, Siwatu, Young, \& Tong, 2015).
These experiences enhance a higher degree of self-efficacy. In this present study, self-efficacy is rated as fair-good however the research is very poor. According to Pajares ,2002 as cited in Büyüköztürk , Atalay, Sozgun \& Şenay Kebapç1, 2011), self-efficacy does not relate to one's actual ability but rather his belief of what he can achieve with it. Thus, it does not follow all the time that one is highly efficacious and can demonstrate the knowledge.

The finding on the positive effect of interest in research on research knowledge implies that if research can excite the curiosity and the respondents' state of wanting to know and learn research, their knowledge in research can be developed positively. Therefore, there is a need to develop the interest of the students to do research by providing varied exposures and research challenges for them that would motivate them do their research engagements.

It is also interesting to note that there is a negative relationship between self-efficacy and research knowledge. The respondents' strong belief in his/ her ability towards research is not a guarantee that he knows a lot about research. Too much confidence may or may not motivate the students to study research more. The tendencies of a certain person being too confident of himself/herself may obscure his/ her curiosity towards research. Since research knowledge involves abilities, it is more than beliefs. Looking closely into the items of the instruments on selfefficacy and interest, the examination reveals that some of the items in the self-efficacy questionnaire are closely related to items in the research interest questionnaire. Some selfefficacy qualities are subsumed in the research interest items. The students rated themselves Good in selfefficacy but their research knowledge is poor. It is possible that their high appraisal of themselves do not match their knowledge in research (Chesnut, Siwatu, Young, \& Tong, 2015).

Furthermore, the results showed a significant effect of research interest on research knowledge. There is a need too, to explore the relationship of self- efficacy to interest in research in future studies.

\section{CONCLUSION}

The results from the survey on research knowledge showed a very poor knowledge on some concepts and poor knowledge on many concepts. The findings showed that Research Knowledge is not accounted by Research Self-efficacy however Research interest is a significant factor that has effect on research knowledge. Another major implication in this study is the distinction between self-efficacy between research self-efficacy and research interest. This two constructs may not have any convergence. These are two distinct concepts. Moreover, this study reveals a major concern among graduate students and should therefore be addressed through interventions and equipping 
activities. Exposure to updates on the different types of researches and improving the system of mentoring the graduate students in terms of research are recommended.

\section{ACKNOWLEDGMENT}

The researchers extends gratitude to the graduate students who participated in this research. This research was also made possible because of the inspiration of our families and colleagues in the School of Education.

\section{REFERENCES}

[1] Amir Tiyuri, Behzad Saberi, Mohammadreza Miri, Ehsan Shahrestanaki, Beyram Bibi Bayat, Hamid Salehiniya (2018). Research self-efficacy and its relationship with academic performance in postgraduate students of Tehran University of Medical Sciences in 2016. J Educ Health Promot. 2018; 7: 11. Published online 2018 Jan 10. doi: 10.4103/jehp.jehp_43_17

[2] Bandura, A. (1994). Social foundations of thought and action: A social cognitive theory. Englewood Cliffs, NJ: Prentice-Hall.

[3] Bocar, Anna C., (Revised 2014). Difficulties Encountered by the Student - Researchers and the Effects on Their Research Output (March 31, 2009). Available at

[4] SSRN: https://ssrn.com/abstract=1612050 or http://dx.doi.org/10.2 139/ssrn.1612050

[5] Büyüköztürk, Ş., Atalay, K., Sozgun, Z., \& Kebapçı, Ş. (2011). The development of research self-efficacy scale. Cypriot Journal of Educational Sciences, 6(1), 22-29.

[6] Chesnut, S. R., Siwatu, K. O., Young, H. A., \& Tong, Y. (2015). Examining the relationship between the re-search training environment, course experiences, and graduate students' research self-efficacy beliefs. International Journal of Doctoral Studies,
10, 399-418. Retrieved http://ijds.org/Volume10/IJDSv10p399-

from

[7] 418Chesnut0914.pdf CMO no. 53, s. 2007. Retrieved from http://www.ched.gov.ph

[8] Congdon, G.J., \& Congdon, S. (2011). Engaging students in a simulated collaborative action research project: An evaluation of a participatory approach to learning. Journal of further and Higher Education, 35(2), 221.Retrieved from https://search.proquest.com/ docview/870470465?accountid=31223

[9] Jang, D., \& Shin I. (2011). The relationship between research selfefficacy and other research constructs: Synthesizing evidence and developing policy implications

through meta-analysis. KEDI Journal of Educational Policy, 8 (2) Retrieved from https://search.proquest.com/ docview/1013972219?accountid $=31223$

[10] Lambie, G. W., Hayes, B. G., Griffith, C., Limberg, D., \& Mullen, P. R. (2014). An exploratory investigation of the research selfefficacy, interest in research, and research knowledge of Ph.D. in education students. Innovative Higher Education, 39(2), 139-153. doi:http://dx.doi.org/ 10.1007/s10755-013-9264-1

[11] Pajares,F. (2009). Self-Efficacy Theory. Retrieved from http://www.education.com/reference/article/self-efficacy-theory/

[12] Potvin, Patrice \& Abdelkrim Hasni (2014). Interest, motivation and attitude towards science and technology at K-12 levels: a systematic review of 12 years of educational research. Studies in Science Education, Volume 50, 2014 Issue 1. http://www.tandfonline.com/doi/full/10.1080/ 03057267.2014 .881626

[13] Rogers, S. W., \& Goktas, R.K. (2010). Exploring engineering graduate student research proficiency with student surveys. Journal of Engineering Education, 99(3), 263-2278.Retrieved from http://search.proquest.com/ docview/744366821 ?accountid=31223 